\title{
Service innovation and internationalization in SMEs: Implications for growth and performance ${ }^{* *}$
}

We investigate the relationship between the management of innovations and internationalization among small- and medium-sized enterprises (SMEs). The literature has yielded mixed results on how innovation impacts internationalization and performance of SMEs, while simultaneously neglecting the role of service innovations (SI), in particular. Thus, using a sample of 104 Finnish SMEs, we examine how engaging in SI impacts their growth, international performance and international expansion. We find that engaging in SI has a positive relationship with international performance, but not with the growth or degree of internationalization (DOI) among the companies. We then discuss the implications on innovation management and corporate strategy.

Key words: service innovation, innovation management, international performance, business growth (JEL: J24, L21, L24, O39)

* Anna Kunttu, Doctoral Student, Lappeenranta University of Technology, School of Business, Skinnarilankatu 34, P.O.BOX 20, 53851 Lappeenranta, Finland.

E-mail: anna.kunttu@lut.fi.

Lasse Torkkeli, PhD., Post-doctoral Researcher, Lappeenranta University of Technology, School Of Business, Skinnarilankatu 34, P.O.BOX 20, 53851 Lappeenranta, Finland.

E-mail: lasse.torkkeli@lut.fi.

** Article received: July 7, 2014

Revised version accepted after double blind review: May 12, 2015. 


\section{Introduction}

This study investigates the influence of service innovation (SI) on strategic outcomes among small and medium-sized enterprises (SMEs). SMEs form the base of economic development in Europe and have been recognized to be important contributors to the recovery from the recession (Ecorys, 2012). The growth and performance of SMEs are driven by how they manage innovation and internationalization (Louart \& Martin, 2012; Hagen, Denicolai, \& Zucchella, 2014; Rask, 2014), and how organizational culture in a small firm can be conducive to both (Knight \& Cavusgil, 2004).

This is noteworthy for various reasons. First, combining innovation and internationalization has been shown to generate the highest growth potential for performance among SMEs (Lecerf, 2012). Second, managing innovation and internationalization may present theoretical and managerial challenges as the two exist intertwined in SMEs and may have common antecedents (see Hagen et al., 2014; Onetti, Zucchella, Jones, \& McDougall-Covin, 2012; Zahra, Ucbasaran, \& Newey, 2009). Third, Dai, Maksimov, Gilbert, and Fernhaber, (2013) have suggested that a moderate level of innovativeness of SMEs could in fact hinder their internationalization efforts, a notion implying that SMEs may be facing a trade-off when aiming to manage internationalization and innovation. Such a trade-off may occur despite the fact that both internationalization and innovation on their own may allow SMEs to accrue strategic and financial benefits. On the other hand, high or low levels of innovativeness increase the scope of internationalization. While the literature, in general, suggests that innovations enhance performance (e.g. Cainelli, Evangelista, \& Savona, 2004; Damanpour, Walker, \& Avellaneda, 2009), more research is needed in the SME context (Edwards, Delbridge, \& Munday, 2005), in particular to find out how SMEs can manage innovation and internationalization simultaneously.

One specific area in need of further study is the role of service innovating. This is because present studies on innovation and business performance in general, and within the SME managerial context in particular, have mostly examined the impact of product- and process innovations rather than service innovations (e.g. Bell, Crick, \& Young, 2004; Trott, 2008; Damanpour \& Gopalakrishnan, 2001; Kotabe \& Murray, 1990). SMEs originating from different countries may also seek to manage their innovation differently and differ in their use of innovation networks (Gretzinger, Hinz, \& Matiaske, 2010), and co-innovating has an impact on both network management of SMEs as well as to their overall internationalization process (Löfgren, 2014).

A service innovation (SI) is understood as a repeatable, significantly new or renewed service generating developer benefits (Toivonen \& Tuominen, 2009). Services have been associated with a limited degree of change as a result of manufacturingdominated models applied in service innovations. This has generated the idea of service innovations being dependent on their supplier as a source of innovation. These issues have been proposed to hinder the attention given by academics, despite their recognized role in building competitive advantage (Tether, 2005). Moreover, some scholars (e.g. Cainelli et al., 2006) have suggested that the relationship between SI and business performance may be more complex than presently understood: some findings even suggest that SMEs could benefit more from general orientation towards in- 
novation than from pure focus on innovative outcomes (Rosenbusch, Brinckmann, \& Bausch, 2011). Thus, innovation management in the context of SI presents a specific challenge to internationalizing SMEs in a practical sense as well as to theoretical research. This, in turn, implies that business performance studies of SMEs in the context of the service industry and innovations are needed.

In the present paper, we seek to respond to these research gaps by clarifying how SI manifests itself in SMEs aiming to innovate and internationalize successfully. In particular, we aim to contribute to existing literature by answering the call for more research combining internationalization and innovation in SME context (e.g. Hagen et al., 2014; Onetti et al., 2012). We extend the results of Kyläheiko, Jantunen, Puumalainen, Saarenketo, and Tuppura, (2011) who examined growth strategies in Finnish companies by focusing specifically on SMEs and service innovations, as well as considering multidimensional measures of degree of internationalization (DOI), growth, and international performance. Moreover, we extend the results of O'Cass and Weerawardena (2009) by considering SI and DOI instead of "organisational innovation intensity" and "international entrepreneurship". Thus, the specific research question we aim to address is: How does service innovation impact the business outcomes in internationally operating SMEs? In a larger view, we thus also seek to shed light on the larger issue of: How can SMEs manage both SI and internationalization, and how does their engagement in the former affect their results in the latter?

The following Section 2 presents a review of the literature on the subject and our hypotheses related to the above research question. Section 3 discusses the chosen methodological approach and gives an overview of the empirical data, which are analyzed in Section 4 and discussed in Section 5. Section 6 concludes the paper with some implications, limitations and suggestions for further research.

\section{Service innovation and business performance in internationalizing SMEs}

Several definitions exist in the literature for SI (Alam, 2006; Avlonitis, Papastathopoulou, \& Gounaris, 2001; Berry \& Lampo, 2000; Berry, Shanker, Parish, Cadwallader, \& Dotzel, 2006; Debackere, Van Looy, \& Papastathopoulou, 1998; Gadrey, Gallouj, \& Weinstein, 1995; Paswan, D’Souza, \& Zolfagharian, 2009). They are commonly defined as a way to fulfill customer needs through an evolutionary process of dynamically combining and recombining service elements (Chae, 2011). The consensus among scholars is that service innovations are multidimensional (Bloch, Aalsteinsdottir, Brehmer, Christensen, Drejer, Hydle, Jensen, Kuusisto, Kvålshaugen, \& Vinding, 2008, p. 15; den Hertog, 2000, 2010; Miles, 2008). In this paper, we refer to SI, in line with den Hertog (2010, p. 19), as a: "new service experience or service solution in one or several of the following dimensions: new service concept, the client interface, new delivery system/organization, and technological options".

Companies increase their degree of internationalization as they gain more information about the market (Johansson \& Vahlne, 1977, 2003, 2009), and as the amount of information increases, so do the possibilities for recognizing opportunities for innovative ideas, whether they arise from unmet needs, regulation, or imitation (Tidd \& Bessant, 2009, p. 230), thus creating possibilities to increase performance in interna- 
tional context. Past studies have repeatedly established a positive relationship between innovation and performance (e.g. Cainelli et al., 2004, 2006; Damanpour et al., 2009; Freel \& Robson, 2004; Hult, Hurley, \& Knight, 2004; Matear, Osborne, Garrett, \& Gray, 2002). Moreover, the connection between innovation and performance has been found in internationalization context, as innovations in global markets influence performance (Hitt, Keats, \& DeMarie, 1998).

Thus, while innovation, let alone SI, has received only limited prior research attention in the context of internationalizing SMEs (e.g. Hagen et al., 2011), there are two main reasons why a positive relationship between SI and performance of internationally operating SMEs could be expected: first-mover advantages and performance gap (Damanpour et al., 2009; Ettlie, 1983; Lieberman \& Montgomery, 1988; Roberts \& Amit, 2003). First-mover advantages are created through innovations, which in turn have an impact on performance (Roberts \& Amit, 2003), while performance gap is created by a change in the environment to which a company is able to adapt to by innovating (Ettlie, 1983).

Sustainable competitive advantage can be only reached through continuous innovating (Porter 1990). In the context of service companies, innovations and innovation capabilities have shown to enhance market and general performance (e.g. Cainelli et al., 2004; Freel \& Robson, 2004; Matear et al., 2002; Grawe, Chen, \& Daugherty, 2009). Furthermore, Cainelli et al. (2006) have proposed a more complex, two-way relationship between innovation and business performance. In the context of internationalization, innovations have been found to impact profitability, performance, and returns on innovations (e.g. Calantone, Cavusgil, Schimidt, \& Shin, 2004; Hitt, Hoskisson, \& Ireland, 1994; Oviatt \& McDougall, 1994).

Product and process innovations may encourage companies to internationalize, and knowledge-intensive companies tend to focus on creating products that can be commercialized internationally (Bell et al., 2004). Indeed, entering several foreign markets simultaneously is one way to overcome R\&D investments (Hitt et al., 1994; Oviatt \& McDougall, 1994). Furthermore, higher export performance can be reached by small companies through an innovative differentiation strategy (Namiki, 1988), and overcoming local disadvantages is made easier for innovating companies that are expanding internationally (Porter, 1990; Hoskisson \& Hitt, 1994, p. 17).

Characteristics, the type of SI as well as innovation characteristics and adaption have been found to influence export performance (Atuahene-Gima, 1995; Calantone et al., 2004; Cavusgil \& Zou, 1994). The radicalness of the innovations and the dynamics of the environment have been suggested to impact SME performance (Freel \& Robson, 2004; McDermott \& Prajogo, 2012). The relationship between innovation and financial performance is affected by the external environment, as a competitive environment combined with incremental innovation enhances financial performance; in a dynamic market environment, financial performance is improved through radical innovation (Jensen, Van Den Bosch, \& Volberda, 2006).

Moreover, incremental process innovation has a positive impact on productivity in the context of service SMEs. In the long term, process and service innovations are key to improved economic performance, although the level of ICT innovation in- 
vestments plays an important role in productivity increases (Freel \& Robson, 2004). When compared to other service sectors, technology-focused service sectors are found to be more innovative (Cainelli et al., 2004; 2006). Nevertheless, companies need to find the balance between different innovation types in order to reach the highest performance benefits instead of focusing on particular types of innovation: innovation adaptation, instead of the specific combination of innovation types may be what results in improved performance (Damanpour et al., 2009). The long-term benefits from innovation activities tend to be utilized more likely by companies that adopt the latest developments in the form of new information. This particularly applies when utilizing innovations to build first-mover advantages (Cohen \& Levinthal, 1990; Roberts \& Amit, 2003).

The performance of a company is also influenced by its innovations in global markets. Higher innovating activity levels have been connected to higher exporting revenues when exporting is considered as an innovative behavior (Samiee, Walters, \& DuBois, 1994). For SMEs in particular, innovator position may have a positive influence in firm performance (Qian \& Li, 2003). Operating in global markets further highlights the relationship between innovations and firm performance (Hitt et al., 1998).

In the context of global start-ups, continuous innovation is a key to retaining competitive advantage. Attaining first-mover position and overcoming limitations are enabled by offering differentiated products and services. Successful new ventures start to internationalize by offering a unique product or service to the industry's lead markets (Oviatt \& McDougall, 1995). Therefore, we hypothesize that:

H1: The level of service innovation in SMEs is positively related to their level of international performance.

The role of $\mathrm{R} \& \mathrm{D}$ investments in building competitive advantage is essential, as $\mathrm{R} \& \mathrm{D}$ investments (measured as percentage of total sales) has shown to enhance subsequent relative growth among international companies (Franko, 1989). Moreover, scholars have also found a positive relationship between sales growth and innovation among service companies (Mansury \& Love, 2008).

Among internationalizing SMEs, innovation may also positively relate to sales growth (Bloodgood, Sapienza, \& Almeida, 1996). Qian and Li's (2003) study also found similar results among SMEs in general, while Hult et al. (2004) noted that the capacity of firms to pursue innovation may positively impact their sales growth in addition to their general performance. In a recent study, Lecerf (2012) suggested that combining internationalization with innovation generates the highest potential for overall growth performance among SMEs. Therefore, we suggest that engaging in SI may be positively related to the growth of internationalizing SMEs:

H2: The level of service innovation in internationally operating SMEs is positively related to their growth.

The combination of internationalization and innovation plays an important role in building and sustaining competitive advantage, especially in SMEs (Hitt et al., 1994; Hoskisson \& Hitt, 1994, p. 85, 147; Porter, 1990). Successful companies are characterized by their tendency to take into consideration global market preferences and needs 
already at the beginning of a new product development process (Kleinschmidt \& Cooper, 1988). Small Nordic innovation-oriented companies are particularly illustrative of rapidly internationalizing SMEs with a global focus (Boter \& Holmquist, 1996). The tendency of small companies to export tends to increase with innovative differentiation strategies (Namiki, 1988).

There have been debates over whether innovation has a moderating effect on the internationalization-business performance relationship (Hitt et al., 1994; Kotabe, Srinivasan, \& Aulakh, 2002), and whether internationalization enhances innovation (e.g. Frenz, Girardone, \& Ietto-Gillies, 2005; Frenz \& Ietto-Gillies, 2007; Zahra, Ireland, \& Hitt, 2000). The positive relationship between firm performance and the degree of internationalization is strengthened by R\&D intensity (Kotabe et al., 2002). Moreover, it has been proposed that the moderating effect of innovation, as a result of process innovation, can lower costs or improve quality, which in turn has a positive impact in international competitiveness (Hitt et al., 1994). Therefore, we suggest that engaging in SI may be positively related to a higher degree of SME internationalization:

H3: The level of service innovation in SMEs is positively related to their degree of internationalization.

\section{Research methodology}

\subsection{Data collection}

Our data comprise Finnish SMEs in the ICT sector and were collected via an online survey in 2013. We selected this empirical context based on theoretical as well as on managerial and institutional considerations. First, SMEs constitute a major economic force in today's global markets. The ICT industry as a whole has been described as global as a result of emerging global standards in telecommunications, for example, which in turn increases the speed of internationalization in order to beat competition (Bell, 1995; Coviello \& Munro, 1997; Saarenketo, Puumalainen, Kuivalainen, \& Kyläheiko, 2004).

Second, the majority (99.8 percent) of companies within the EU are SMEs, being significant employers within the non-financial business economy providing 67.4 percent of jobs (Ecorys 2012). Moreover, at the EU level, the ICT sector has been recognized as being among the most innovative sectors with growth primarily achieved through internationalization (Aslesen, 2008; Moen, Gavlen, \& Endresen, 2004; Saarenketo et al., 2004).

Third, survival in high-tech sectors requires innovating, which in turn pushes companies towards internationalization as a way to grow and overcome high costs of innovating (Cefis \& Marsili, 2006; Saarenketo et al., 2004). As a result of these trends, technological innovation has received considerably more attention compared to service innovation, making high-tech industries particularly relevant for studying the impact of SI on performance outcomes. Fourth, investigating the phenomenon within the empirical setting - a small open economy such as Finland - is fitting for a variety of reasons. The role of the ICT sector is essential to Finnish economic development and its activity level in Finland is among the leading countries globally (Dutta \& Bilbao- 
Osorio, 2012). Additionally, the Finnish ICT sector comprises small- and mediumsized companies, and has been recognized as innovative on a global scale - the national total of ICT-related patents was the second highest globally during 2004-2009 (OECD, 2012). Given the above reasons, we deemed the context of Finnish SMEs operating within the ICT sector as a particularly relevant research setting for the purposes of this study.

Suitable companies were identified through the online database, Amadeus, by using the European Commission classification of ICT companies and SMEs, i.e., companies employing less than 250 employees and with a turnover equal to or less than EUR 50 million (European Commission, 2005). We identified the ICT industries based on the NACE Rev. 2 classification (Mas, Robledo, \& Perez, 2012). In order to collect the data, we constructed an online survey, which was piloted by two managers with different backgrounds. Based on their suggestions, some minor changes were made to the wordings of some items. The target companies were contacted first via email containing a cover letter and a link to the online survey. Non-respondents were contacted via three reminder emails: the first reminder was sent three weeks after the initial e-mail and then at two-week intervals.

In total we contacted 1,050 companies, of which 46 were excluded due to either their lack of international operations or due to their inability to partake in an online survey. From the remaining 1,004 companies, we received 104 responses during the two months (March-February 2013) of data collection, a 10 percent response rate. One reason for the somewhat low response rate may have been that certain questions relating to firm performance may be considered as too sensitive information by Finnish SMEs to be given in a survey (see Autio, Sapienza, H. J., \& Almeida, 2000).

The average age of the respondent companies was 13 years, and the majority (79.7 percent) had sales of less than EUR 5 million. Of the respondents, 76.6 percent were CEOs and 50 percent had eight or more years of international experience and on average 5.5 years industry experience. The survey also included items on the company size (measured in total sales) and on the number of fulltime employees. We included these items in order to evaluate their potential impact on innovating, as suggested in earlier studies (Andersson, 2000; Manolova, Brush, Edelman. \& Greene, 2002; Reuber \& Fischer, 1997; Ruzzier, Antoncic, Hisrich, \& Konecnik, 2007).

\subsection{The measures and scale development}

The reliability and validity of the used scales were assessed through factor analysis, determined to be appropriate to use due to small partial correlations. Kaiser's measure of sampling adequacy (MSA) should receive values above 0.5 in order to be adequate (Hair, Anderson, Tatham \& Black, 1998, p. 99). Uncorrelated factors are created and data structures simplified by using a Varimax rotation - a common method. The item is considered low if the item communalities are less than 0.4 , and high if they are 0.8 or greater (Costello \& Osborne, 2005). As Table 1 shows, all Cronbach's alpha values are above 0.7 , indicating that all the resulting factor analyses are reliable, as Hair et al. (1998) recommended.

Four Likert-scaled items, following Sullivan (1994), were used to measure DOI. The item for "percentage of your employees that are located outside of the company's home country" 
was discarded due to poor fit to the DOI factor. The three DOI items in the survey formed a single factor, which explained 92 percent of total variance. The MSA (0.67-0.88) and communality (0.65-0.92) values suggested a valid and reliable factor. The notion of Sullivan (1994) to use multi-dimensional measure for operationalization is supported by results of the factor analysis, shown in Table 1. Additionally, six Likert-scaled items, adapted from Cooper and Kleinschmidt (1987), were used to measure SI. Although these measures were originally developed for measuring product innovation, they have also been used in the service context (e.g. Atuahene-Gima \& Ko, 2001; Radulovich, 2008). Due to a poor fit to the factor, three items were discarded

Table 1: Rotated factor loadings for the applied measures

\begin{tabular}{|c|c|c|c|}
\hline \multicolumn{4}{|c|}{ Degree of Internationalization (DOI) } \\
\hline & & Comm. & MSA \\
\hline DOI1 & 0.957 & 0.916 & 0.67 \\
\hline DOI2 & 0.806 & 0.649 & 0.88 \\
\hline DOI3 & 0.933 & 0.870 & 0.69 \\
\hline Var exp. & 0.812 & & \\
\hline Cum. var. & 0.812 & & \\
\hline Cron. alpha & 0.924 & & \\
\hline \multicolumn{4}{|c|}{ Service Innovation (SI) } \\
\hline SI1 & 0.875 & 0.765 & 0.68 \\
\hline $\mathrm{SI} 5$ & 0.795 & 0.632 & 0.73 \\
\hline $\mathrm{SI} 6$ & 0.756 & 0.571 & 0.76 \\
\hline Var exp. & 0.656 & & \\
\hline Cum. var. & 0.656 & & \\
\hline Cron. alpha & 0.846 & & \\
\hline \multicolumn{4}{|c|}{ International Performance } \\
\hline P4 & 0.974 & 0.948 & 0.71 \\
\hline P5 & 0.928 & 0.861 & 0.80 \\
\hline P6 & 0.927 & 0.859 & 0.80 \\
\hline Var exp. & 0.889 & & \\
\hline Cum. var. & 0.889 & & \\
\hline Cron. alpha & 0.959 & & \\
\hline \multicolumn{4}{|c|}{ Growth } \\
\hline P7 & 0.818 & 0.669 & 0.73 \\
\hline P8 & 0.811 & 0.657 & 0.74 \\
\hline P9 & 0.957 & 0.916 & 0.63 \\
\hline Var exp. & 0.748 & & \\
\hline Cum. var. & 0.748 & & \\
\hline Cron. alpha & 0.895 & & \\
\hline
\end{tabular}

(Var exp. = variance explained, Cum. var. = cumulative variance and Cron. alpha $=$ Cronbach's alpha $)$ 
due to low communality values. The three remaining SI items were combined to form a single factor, which explained 65.6 percent of the total variance. The MSA (0.68-0.73) and communality values (0.57-0.77) suggested a valid and reliable factor. The items that comprised the final SI factor were as follows: (1) "Our service(s) offer unique benefits to the customer not offered by competitors"; (2) "Our service(s) are highly innovative, replacing a vastly inferior alternative"; and (3) "Our service(s) offers solutions that are not possible to achieve with existing products". Cronbach's alpha (0.85) indicated further reliability for the three-item scale.

Second, we measured growth and international performance via subjective scales comprising a set of seven-point Likert items, in which the respondents were asked to evaluate their company's growth and international performance over the past three years relative to their competitors (see Appendix A). Two factors for growth (items in line with Dobbs \& Hamilton, 2007; Chandler \& Hanks, 1993) and international performance (items in line with Autio et al., 2000; Cavusgil \& Zou, 1994; Knight, 2001; Zahra \& Garvis, 2000) were formed from the performance items. The measure can be considered acceptable for the analysis as both the resulting factors had high Cronbach's alpha values $(0.90$ and 0.96$)$ and they explained the sufficient amount of the total variation (75 and 89 percent, respectively).

Last, we included several general items that explored the characteristics of the companies and their management: we asked the respondents to specify the subindustry sector of their ICT company (see appendix A) - the literature has suggested that a company's industrial sector and size can be significant factors in influencing its internationalization process (Bell, 1995; Bell et al., 2004; Pla-Barber \& Escriba-Esteve, 2006). The industrial sector was subsequently re-coded into a three-category control variable. We also included the age of the company as a control variable as it has been known to impact the international sales and performance of smaller, younger companies in particular (Reuber \& Fischer, 1997; Zahra, 2003). Further, as both internationalization and innovation can be influenced by the management's international and industry experience (e.g., Andersson, 2000; Manolova et al., 2002; Reuber \& Fischer, 1997; Ruzzier et al., 2007), we also included them as control variables in our analysis. The descriptives and intercorrelations between the variables used in hypotheses testing are illustrated in Table 2.

Table 2: The descriptives and intercorrelations of the variables used in hypotheses testing

\begin{tabular}{l|c|c|c|c|c|c|c|c|c}
\hline & Mean & Std. & DOI & SI & Growth & Int. Perf. & Size & Age & Sector \\
\hline DOI & 0.01 & 1.03 & 1.00 & & & & & & \\
\hline SI & 0.00 & 0.94 & -0.04 & 1.00 & & & & & \\
\hline Growth & -0.05 & 1.07 & -0.11 & 0.11 & 1.00 & & & & \\
\hline Int. Perf. & -0.05 & 1.04 & $0.55^{* *}$ & $0.35^{* *}$ & 0.20 & 1.00 & & & \\
\hline Size & 0.09 & 0.29 & 0.11 & -0.08 & 0.00 & 0.08 & 1.00 & & \\
\hline Age & 15.82 & 10.22 & 0.00 & $-0.29^{*}$ & -0.21 & -0.08 & 0.15 & 1.00 & \\
\hline Sector & 2.55 & 0.86 & $-0.27^{*}$ & $0.22^{*}$ & 0.13 & -0.17 & 0.17 & $-0.45^{* *}$ & 1.00 \\
\hline
\end{tabular}


We then further considered the reliability and validity of our applied scales as follows. Fornell and Larcker (1981) have suggested a three-step model for convergent and discriminant validity, where significant indicator factor loadings are first required. Second, composite reliability (CR) should exceed 0.70 (Hair et al., 1998, p. 612), and third, the average variance expected (AVE) of each construct should exceed 0.50 . Lastly, adequate discriminant validity is reached when the shared variance for all factors is exceeded by the square root of the AVE value (Fornell \& Larcker, 1981). Based on the values illustrated in Table 3, we can conclude that there was convergent and discriminant validity in our constructs as all the above requirements were met.

Table 3: Construct and discriminant validity.

\begin{tabular}{l|c|c|c|c|c|c}
\hline \multicolumn{1}{c|}{ Construct } & & & \multicolumn{5}{c}{ Shared variance among constructs } \\
\hline & CR & AVE & DOI & SI & Growth & Int. Perf. \\
\hline DOI & 0.97 & 0.81 & $(\mathbf{0 . 9 0 )}$ & & & \\
\hline SI & 0.92 & 0.65 & $-0.06^{*}$ & $(0.81)$ & & \\
\hline Growth & 0.95 & 0.73 & $-0.05^{*}$ & $0.12^{*}$ & $(0.85)$ & \\
\hline Int. performance & 0.98 & 0.89 & $0.55^{*}$ & $0.38^{*}$ & $0.67^{*}$ & $(0.95)$ \\
\hline
\end{tabular}

\section{Results}

We conducted a linear regression analyses in order to examine the impact of SI on company performance and growth. The results, illustrated in Table 4, overall indicate that SI had a statistically significant and positive impact on the international performance of SMEs (H1). The international performance regression model was statistically significant $\left(\mathrm{p}<0.05\right.$, adj. $\left.\mathrm{R}^{2}=0.17\right)$, and thus the results on the SI-performance relationship indicated that higher levels of international performance could be explained by more innovative activities.

Subsequently, we conducted further linear regression analysis in order to test for the impact of SI on growth (H2) and the DOI (H3) of the companies. These results, also illustrated in Table 4 , indicate that neither the growth model ( $\mathrm{p}>0.05$, adj. $\mathrm{R}^{2}=$ $0.01)$ nor the DOI model $\left(\mathrm{p}>0.05\right.$, adj. $\left.\mathrm{R}^{2}=0.05\right)$ were statistically significant at the 5 percent risk level. Thus, we did not find a statistically significant connection between service innovation and higher growth of the companies or between service innovation and higher degrees of internationalization, and therefore neither $\mathrm{H} 2$ nor $\mathrm{H} 3$ were supported by the analysis.

Moreover, of the three control variables (industry sector, size and age of the company) the only one with significant impact in the models was the industry sector, and only significant in the international performance model $(p<0.05)$. This result implied that the industry sector had a negative influence, suggesting that companies operating in the service industry decrease international performance.

As the literature suggests that the relationship can be two-way, (Cainelli et al., 2006) we also tested the DOI-SI relationship. Contrary to the SI-DOI relationship, the model was significant at a 10 percent risk level. Additionally, the control variables were all significant $(\mathrm{p}<0.1-0.01)$, although SI did not have an impact on DOI. The results suggest, contrary to prior literature, that there does not seem to be connection between SI and DOI. On the other hand, this insignificancy might imply, as hypothe- 
sized in the literature, that the relationship between service innovation and international expansion could be more complicated than a linear relationship (Cainelli et al., 2006), such as curvilinear or it might be impacted by other factors than those included in the analysis.

Table 4: Regression analyses for DOI, SI and performance (H1-H3).

\begin{tabular}{l|c|c|c|c}
\hline \multicolumn{1}{c|}{ Model } & $\begin{array}{c}\text { International perfor- } \\
\text { mance }\end{array}$ & Growth & DOI & SI \\
\hline SI & $\mathbf{0 . 3 9 ^ { * * }}$ & 0.04 & -0.03 & \\
\hline DOI & & & & -0.04 \\
\hline Sector & $-0.41^{*}$ & -0.07 & 0.18 & $-0.53^{* *}$ \\
\hline Firm Size & 0.45 & 0.08 & 0.05 & $0.66^{\prime}$ \\
\hline Firm Age & -0.01 & -0.02 & -0.02 & $-0.02^{\prime}$ \\
\hline R-square & 0.17 & 0.05 & 0.10 & 0.13 \\
\hline Adjusted R-square & 0.12 & -0.01 & 0.05 & 0.07 \\
\hline F & $3.51^{*}$ & 0.83 & 1.92 & $2.44^{\prime}$ \\
\hline
\end{tabular}

\section{Discussion and conclusions}

Our aim in this study was to examine the impact that engaging in SI has on the growth and foreign expansion of high-technology SMEs. In doing so, we sought to fill several gaps in the literature related to the management of innovations and internationalization among small firms; to respond to the lack of studies investigating SI in particular; and to investigate the context of high-technology SMEs, i.e., those companies that often face pressure to both innovate and internationalize simultaneously, despite limited resources. By examining a sample of Finnish ICT SMEs, our results showed that higher levels of SI have a positive impact on their international performance, which is, in turn, a sustainable way to build competitive advantage (as suggested by Hitt et al., 1994 and Porter, 1990).

On the other hand, the hypotheses on the SI and business performance relationship were only partially supported as we found that neither the growth nor the degree of internationalization of the companies was significantly impacted by their engagement in SI. These non-significant relationships may be caused, for instance, by the relative radicalness of service innovations. McDermott and Prajogo (2012) have suggested this to be the case by finding that ambidextrous innovation, balancing the radicalness of innovations, may be required for a significant impact to occur.

Our results also imply that, as SMEs proceed in their internationalization process, they should not forget innovating since it can help them to overcome local disadvantages (see Porter, 1990). Unlike O'Cass and Weerawardena (2009), we found that only service innovation enhances international performance. Moreover, our findings regarding growth contradict with the prior literature on the topic that has suggested that for SMEs internationalization and innovation are a way to survive and grow (Hollensen, 2007, p. 74-75; Louart \& Martin, 2012), as we could not find link between SI and higher growth among SMEs. These results also contradict with findings of Kyläheiko et al. (2011), who propose that highest growth is achieved innovating do- 
mestically. In response, we note that as SMEs, and rapidly internationalizing hightechnology SMEs in particular face resource constraints (Knight \& Cavusgil, 2004), it may take time before the benefits from innovating are realized. As Rogers (2003) maintains, consumers only gradually abandon an old service and adopt a new one, thus creating a time lag between growth and SI. We note this as a limitation in our present study, as ours was a survey sample instead of a longitudinal investigation. Thus, future studies could examine the possibility for such a lag, and in doing so could yield further insights into how the dynamics of engaging in and managing SI impact the survival, growth and foreign expansion among SMEs.

In conclusion, we see that the findings of this study contribute both to the literature on determinants of firm performance and to that of successful internationalization of high-technology SMEs (Bell, 1995; Madsen \& Servais, 1997; Knight \& Cavusil, 2004). Our findings also contribute to innovation management regarding the capture of benefits from innovation (Greztinger et al., 2010; Tidd \& Bessant, 2009, p. 531). In particular, our results extend the knowledge on SI in the context of internationally operating SMEs by suggesting that SMEs concentrating on SI may be able to gain certain performance benefits by operating internationally; however, accruing these benefits may be complex and dependent on the strategic goals and the type of desired performance outcomes. This notion further implies that aiming to manage both innovation and internationalization presents a challenge for SMEs in general, and to hightechnology SMEs in need of intensive innovation and internationalization in particular.

We also note several additional limitations to our present study. First, it only focuses on a single country and a single industry, which limits the generalizability of the results. In order to provide support for the suggested model, it should be applied across industries and countries - a cross-country study, for example, could provide more evidence on the applicability of the theoretical models. Using panel data would also allow more detailed examination of SI-performance relationships. Second, the sample data mainly consisted of small service companies in the ICT industry and the measures used were mainly self-reported, meaning that the results are mostly based on the subjective evaluations of managers. Third, we did not consider the effects of different types of innovation such as SI in comparison to product innovation. Lastly, causality of proposed relationships limits our possibilities to examine the complex innovation-international performance relationship. Future research should examine the two-way relationship of innovation and international performance over time.

Future research should also consider the different types and radicalness of service innovations, as different degrees of radicalness create different types of competitive advantage (e.g. Tidd, 2001); comparing SI and product innovation, for example, could also be beneficial. Second, future research could investigate in more depth the antecedents of SI and examine possible mediator and moderator effects (see FernándezMesa \& Alegre, 2015). Additionally, profitability as an outcome of SI could be investigated, as both SI and DOI have been suggested to have a positive impact on profitability, especially in the service context (e.g. Cainelli et al., 2004, 2006; Contractor et al., 2007; Damanpour et al., 2009; Freel \& Robson, 2004). 
Finally, careful examination of human capital, social capital and entrepreneurial orientation as antecedents of SI could provide interesting findings to both academics and practitioners. SMEs have a tendency to compensate other resources with human capital (Westhead, Wright, \& Ucbasaran, 2001) while social capital has been recognized to be important to both innovation (Casanueva \& Gallego, 2010) and internationalization (e.g Chesbrough 2011, p. 35; Johansson \& Vahlne, 2013). For example, investigating SI from the point of view of innovation networks (see Gretzinger et al., 2010) may provide increasingly deeper insight into the dynamics of service innovating within clusters. This would further help link innovation management (Quinn, 1985; Adams et al., 2006; Trott, 2008) and network management (Möller \& Halinen, 1999; Ritter \& Gemünden, 2003), thus extending the work of Gretzinger, Hinz and Matiaske (2010) and Löfgren (2014) to include the SI context in particular.

\section{References}

Alam, I. (2006). Service innovation strategy and process: A cross-national comparative analysis. International Marketing Review, 23(3), 234-254.

Anderson, D. R., Sweeney, D. J., \& Williams, T. A. (2005). Statistics for business and economics. Mason, OH: Thomson South-Western.

Aslesen, H. W. (2008). Prospective innovation challenges in the ICT sector. Europe Innova Report.

Atuahene-Gima, K. (1995). The influence of new product factors on export propensity and performance: An empirical analysis. Journal of International Marketing, 3(2), 11-28.

Atuahene-Gima, K., \& Ko, A. (2001). An empirical investigation of the effect of market orientation and entrepreneurship orientation alignment on product innovation. Organization Science, 12(1), 54-74.

Autio, E., Sapienza, H. J., \& Almeida, J. G. (2000). Effects of age at entry, knowledge intensity, and imitability on international growth. Academy of Management Journal, 43(5), 909-924.

Avlonitis, G. J., Papastathopoulou, P. G., \& Gounaris, S. P. (2001). An empirically-based typology of product innovativeness for new financial services: Success and failure scenarios. The Journal of Product Innovation Management, 18(5), 324-342.

Bell, J. (1995). The internationalization of small computer software firms: A further challenge to "stage" theories. European Journal of Marketing, 29(8), 60-75.

Bell, J., Crick, D., \& Young, S. (2004). Small firm internationalization and business strategy. International Small Business Journal, 22(1), 23-56.

Berry, L. L., \& Lampo, S. K. (2000). Teaching an old service new tricks: The promise of service redesign. Journal of Service Research, 2(3), 265-275.

Berry, L. L., Shanker, V., Parish, J. T., Cadwallader, S., \& Dotzel, T. (2006). Creating new markets through service innovation. MIT Sloan Management Review, 47(2), 374-391.

Bloch, C., Aalsteinsdottir, E., Brehmer, P. O., Christensen, J. L., Drejer, I., Hydle, K., Jensen, M. B., Kuusisto, J., Kvålshaugen, R., \& Vinding, A. L. (2008). Service innovation in the Nordic Countries: Key factors for policy design. Retrieved 22.03.2013, from

http://ps.au.dk/fileadmin/site_files/filer_forskningsanalyse/dokumenter/Forskningsprojekter/Ser vINNo/servinno_final_report.pdf.

Bloodgood, J. M., Sapienza, H. J., \& Almeida, J. G. (1996). The internationalization of new high-potential U.S. ventures: Antecedents and outcomes. Entrepreneurship Theory and Practice, 20(4), 61-76.

Boter, H., \& Holmquist, C. (1996). Industry characteristics and internationalization processes in small firms. Journal of Business Venturing, 11(6), 439-532.

Calantone, R. J., Cavusgil, S. T., Schimidt, J. B., \& Shin, G-C. (2004). Internationalization and the dynamics of product adaptation - An empirical investigation. Journal of Product Innovation Management, 21(3), 185-198.

Cainelli, G., Evangelista, R., \& Savona, M. (2006). Innovation and economic performance in services: A firm-level analysis. Cambridge Journal of Economics, 30(3), 435-458.

Cainelli, G., Evangelista, R., \& Savona, M. (2004). The impact of innovation on economic performance in services. The Service Industries Journal, 24(1), 116-130. 
Casanueva, C., \& Gallego, Á. (2010). Social capital and innovation: An intra-departmental perspective. Management Revue, 21(2), 135-154, DOI: 10.1688/1861-9908_mrev_2010_02_Casanueva.

Cavusgil, S. T., \& Zou, S. (1994). Marketing strategy-performance relationship: An investigation of the empirical link in export market ventures. Journal of Marketing, 58(1), 1-22.

Cefis, E., \& Marsili, O. (2006). Innovation premium and the survival of entrepreneurial firms in the Netherlands. In: E. Santarelli (ed.), Entrepreneurship, growth, and innovation (pp. 183-198). New York, NY: Springer Science and Business Media.

Chae, B. K. (2011). An evolutionary framework for service innovation: Insights of complexity theory for service science. International Journal of Production Economics, 135(2), 813-822.

Chandler, G. N., \& Hanks, S. H. (1993). Measuring the performance of emerging businesses: A validation study. Journal of Business Venturing, 8(5), 391-408.

Chesbrough, H. W. (2011). Open services innovation: Retbinking your business to grow and compete in a new era. San Francisco, CA: Jossey-Bass.

Cohen, W. M., \& Levinthal, D. A. (1990). Absorptive capacity: new perspective on learning and innovation. Administrative Science Quarterly, 35(1), 128-52.

Contractor, F. J., Kumar, V., \& Kundu, S. K. (2007). Nature of the relationship between international expansion and performance: The case of emerging market firms. Journal of World Business, 42(4), 401417.

Cooper, R. G., \& Kleinschmidt, E. J. (1987). New products: What separates winners from losers?. Journal of Product Innovation Management, 4(3), 169-184.

Costello, A. B., \& Osborne, J. W. (2005). Best practices in exploratory factor analysis: Four recommendations for getting the most from your analysis. Practical Assessment, Research and Evaluation, 10(7), 1-9.

Coviello, N., \& Munro, H. (1997). Network relationships and the internationalization process of small software firm. International Business Review, 6(4), 361-386.

Dai, L., Maksimov, V., Gilbert, B. A., \& Fernhaber, S. A. (2014). Entrepreneurial orientation and international scope: The differential roles of innovativeness, proactiveness, and risk-taking. Journal of Business Venturing, 29(4), 511-524.

Damanpour, F. (1991). Organizational innovation: A meta-analysis of effects of determinants and moderators. Academy of Management Journal, 34(3), 555-590.

Damanpour, F., \& Gopalakrishnan, S. (2001). The dynamics of the adoption of product and process innovations in organizations. Journal of Management Studies, 38(1), 45-65.

Damanpour, F., Walker, R. M., \& Avellaneda, C. N. (2009). Combinative effects of innovation types and organizational performance: A longitudinal study of service organizations. Journal of Management Studies, 46(4), 650-675.

Debackere, K., Van Looy, B., \& Papastathopoulou, P. (1998). Managing innovation in a service environment. In: R. Van Dierdonck, B. Van Looy \& P. Gemmel (eds.), Service management: An integrated approach (pp. 404-426). Harlow: Pearson Education.

den Hertog, P., van der Aa, W., \& de Jong, M. A. (2010). Capabilities for managing service innovation: towards a conceptual framework. Journal of Service Management, 21(4), 490-514.

den Hertog, P. (2000). Knowledge intensive business services as co-producers of innovation. International Journal of Innovation Management, 4(4), 491-528.

Dobbs, M., \& Hamilton, R. T. (2007). Small business growth: Recent evidence and new directions. International Journal of Entrepreneurial Behaviour and Research, 13(5), 296-322.

Dutta, S., \& Bilbao-Osorio, B. (2012). The Global Information Technology Report 2012: Living in Hyperconnected World. Retrieved 09.04.2013, from http://www3.weforum.org/ docs/Global_IT_Report_2012.pdf.

Ecorys. (2012). EU SMEs in 2012: at the crossroads. Retrieved 15.11.2012, from http://ec.europa.eu/enterprise/policies/sme/facts-figures-analysis/performance-review/files/ supporting-documents/2012/annual-report_en.pdf.

Edwards, T., Delbridge, R., \& Munday, M. (2005). Understanding innovation in small and medium-sized enterprises: a process manifest. Technovation, 25(10), 1119-1127.

Ettlie, J. H. (1983). Performance gap theories of innovation. IEEE Transactions on Engineering Management, 30(2), 39-52. 
European Commission. (2005). Small and medium-sized enterprises (SMEs) What is an SME? Retrieved 19.02.2013, from http://ec.europa.eu/enterprise/policies/sme/facts-figures-analysis/sme-definition/.

Fernández-Mesa, A., \& Alegre, J. (2015). Entrepreneurial orientation and export intensity: Examining the interplay of organizational learning and innovation. International Business Review, 24(1), 148-156.

Fornell, C., \& Larcker, D. F. (1981). Evaluating structural equation models with unobservable variables and measurement error. Journal of Marketing Research, 18(1), 39-50.

Franko, L. O. (1989). Global corporate competition: Who's winning, who's losing, and the R\&D factor as one reason Why. Strategic Management Journal, 10(5), 449-474.

Freel, M. S., \& Robson, P. J. A. (2004). Small firm innovation, growth and performance: Evidence from Scotland and Northern England. International Small Business Journal, 22(6), 561-575.

Frenz, M., Girardone, C., \& Ietto-Gillies, G. (2005). Multinationality matters in innovation: The case of the UK financial services. Industry and Innovation, 12(1), 65-92.

Frenz, M., \& Ietto-Gillies, G. (2007). Does multinationality affect the propensity to innovate? An analysis of the third UK Community Innovation Survey. International Review of Applied Economics, 21(1), 99_ 117.

Gadrey, J., Gallouj, F., \& Weinstein, O. (1995). New modes of innovation: How services benefit industry. International Journal of Service Industry Management, 6(3), 4-16.

Giardini, A., \& Frese, M. (2007). Affective complementarity in service encounters. Management Revue, 18(1), 75-87.

Grawe, S. J., Chen, H., \& Daugherty, P. J. (2009). The relationship between strategic orientation, service innovation, and performance. International Journal of Physical Distribution and Logistics Management, 39(4), 282-300.

Gretzinger, S., Hinz, H., \& Matiaske, W. (2010). Cooperation in innovation networks: The case of Danish and German SMEs. Management Revue, 21(2), 193-216, DOI: 10.1688/1861-9908_mrev_2010_02_Gretzinger.

Hagen, B., Denicolai, S., \& Zucchella, A. (2014). International entrepreneurship at the crossroads between innovation and internationalization. Journal of International Entrepreneurship, 12(2), 111-114.

Hair, J. F., Anderson, R. E., Tatham, R. L., \& Black, W. C. (1998). Multivariate data analysis. Englewood Cliffs, NJ; Prentice-Hall.

Hitt, M. A., Hoskisson, R. E., \& Ireland, R. D. (1994). A mid-range theory of the interactive effects of international and product diversification on innovation and performance. Journal of Management, 20(2), 297-326.

Hitt, M. A., Keats, B. W., \& DeMarie, S. M. (1998). Navigating in the new competitive landscape: Building strategic flexibility and competitive advantage in the $21^{\text {st }}$ century. Academy of Management Review, 12(4), 22-42.

Hollensen, S. (2007). Global Marketing. A decision-oriented approach. Harlow: Pearson Education Limited.

Hoskisson, R. E., \& Hitt, M. A. (1994). Downscoping: How to tame the diversified firm. New York, NY: Oxford University Press.

Hult, G. T. M., Hurley, R. F., \& Knight, G. A. (2004). Innovativeness: Its antecedents and impact on business performance. Industrial Marketing Management, 33(5), 429-428.

Jensen, J. J., Van Den Bosch, F. A., \& Volberda, H. W. (2006). Exploratory innovation, exploitative innovation and performance: Effects of organizational antecedents and environmental moderators. Management Science, 52(11), 1661-1674.

Johansson, J., \& Vahlne, J-E. (2013). The Uppsala model on evolution of the multinational business enterprise - From internalization to coordination of networks. International Marketing Review, 30(3), 189-210.

Johanson, J., \& Vahlne, J-E. (1977). The internationalization process of the firm - A model of knowledge development and increasing foreign market commitments. Journal of International Business Studied, 8(1), 23-32.

Johanson, J., \& Vahlne, J.-E. (2003). Business relationship learning and commitment in the internationalization process. Journal of International Entrepreneurship, 1(1), 83-101.

Johanson, J., \& Vahlne, J.-E. (2009). The Uppsala internationalization process model revisited: From liability of foreignness to liability of outsidership. Journal of International Business Studies, 40(9), 14111431. 
Kleinschmidt, E. J., \& Cooper, R. G. (1988). The performance impact of an international orientation on product innovation. European Journal of Marketing, 22(10), 56-71.

Knight, G. A. (2001). Entrepreneurship and strategy in the international SME. Journal of International Management, 7(3), 155-171.

Knight, G. A., \& Cavusgil, S. T. (2004). Innovation, organizational capabilities, and the born-global firm. Journal of International Business Studies, 35(2), 124-141.

Kotabe, M., \& Murray, J. Y. (1990). Linking product and process innovations and modes of international sourcing in global competition: A case of foreign multinational firms. Journal of International Business Studies, 21(3), 383-408.

Kotabe, M., Srinivasan, S. S., \& Aulakh, P. S. (2002). Multinationality and firm performance: the moderating role of marketing and R\&D activities. Journal of International Business Studies, 33(1), 79-97.

Kyläheiko, K., Jantunen, A., Puumalainen, K., Saarenketo, S., \& Tuppura, A. (2011). Innovation and internationalization as growth strategies: The role of technological capabilities and appropriability. International Business Review, 20(5), 508-520.

Lecerf, M. (2012). Internationalization and innovation: The effects of a strategy mix on the economic performance of French SMEs. International Business Research, 5(6), 2-13.

Lieberman, M. B., \& Montgomery, D. B. (1988). First-mover advantages. Strategic Management Journal, 9(5), 41-58.

Louart, P., \& Martin, A. (2012). Small and medium-sized enterprises and their attitudes towards internationalization and innovation. International Business Research, 5(6), 14-23.

Löfgren, A. (2014). International network management for the purpose of host market expansion: The mediating effect of co-innovation in the networks of SMEs. Journal of International Entrepreneurship, 12(2), 162-182.

Manolova, T. S., Brush, C. G., Edelman, L. F., \& Greene, P. G. (2002). Internationalization of small firms: International factors revisited. International Small Business Journal, 20(1), 9-13.

Mansury, M. A., \& Love, J. H. (2008). Innovation, productivity and growth in US business services: A firm-level analysis. Technovation, 28(1-2), 52-63.

Mas, M., Robledo, J. C., \& Perez, J. (2012). ICT sector definition transition from NACE Rev. 1.1 to NACE Rev. 2. Retrieved 14.1.2013, from http://is.jrc.ec.europa.eu/pages/ISG/PREDICT/2da/documents/PREDICTWPICTSectorDefinitionTransition.pdf.

Madsen, T.K., \& Servais, P. (1997). The internationalization of born globals: An evolutionary process? International Business Review, 6(6), 561-583.

Matear, S., Osborne, P., Garrett, T., \& Gray, B. J. (2002). How does market orientation contribute to service firm performance? An examination of alternative mechanisms. European Journal of Marketing, 36(9), 1058-1075.

McDermott, C. M., \& Prajogo, D. I. (2012). Service innovation and performance in SMEs. International Journal of Operations and Production Management, 32(2), 216-237.

Miles, I. (2008). Patterns of innovation in service industries. IBM Systems Journal, 47(1), 115-128.

Moen, Ø., Gavlen, M., \&Endresen, I. (2004). Internationalization of small, computer software firms: Entry forms and market selection. European Journal of Marketing, 38(9/10), 1236-1251.

Möller, K., \& Halinen, A. (1999). Business relationships and networks: Managerial challenge of network era. Industrial Marketing Management, 28(5), 413-427.

Namiki, N. (1988). Export Strategy for Small Business. Journal of Small Business Management, 26(2), 25-31.

O'Cass, A., \& Weerawardena, J. (2009). Examining the role of international entrepreneurship, innovation and international market performance in SME internationalization. European Journal of Marketing, $43(11 / 12), 1325-1348$.

OECD. (2012). Share of countries in ICT-related patents filed under the PCT. Retrieved 09.04.2013, from http:// www.oecd.org/sti/ieconomy/oecdkeyictindicators.htm.

Onetti A., Zucchella, A., Jones, M. V., \& McDougall-Covin, P. P. (2012). Internationalization, innovation and entrepreneurship: Business models for new technology-based firms. Journal of Management and Governance, 16(3), 337-368.

Oviatt, B. M., \& McDougall, P. P. (1995). Global start-ups: Entrepreneurs on a worldwide stage. The Academy of Management Executive, 9(2), 30-44. 
Oviatt, B. M., \& McDougall, P. P. (1994). Toward a theory of international new ventures. Journal of International Business Studies, 25(1), 45-64.

Paswan, A., D’Souza, D., \& Zolfagharian, M. A. (2009). Toward a contextually anchored service innovation typology. Decision Sciences, 40(3), 513-540.

Pla-Barber, J., \& Escriba-Esteve, A. (2006). Accelerated internationalization: evidence from a late investor country. International Marketing Review, 23(3), 255-278.

Porter, M. E. (1990). The competitive advantage of nations. Harvard Business Review, 68(2), 73-93.

Qian, G., \& Li, L. (2003). Profitability of small- and medium-sized enterprises in high-tech industries: The case of the biotechnology industry. Strategic Management Journal, 24(9), 881-887.

Quinn, J. B. (1985). Managing innovation: Controlled chaos. Harvard Business Review, 63(3), 73-84.

Radulovich, L. P. (2008). An empirical examination of the factors affecting the internationalization of professional service SMEs: The case of India. Cleveland, OH: Cleveland State University.

Rask, M. (2014). Internationalization through business model innovation: In search of relevant design dimensions and elements. Journal of International Entrepreneurship, 1-16.

Reuber, R. A., \& Fischer, E. (1997). The influence of the management team's international experience on the internationalization behaviours of SMEs. Journal of International Business Studies, 2(4), 807-826.

Ritter, T., \& Gemünden, H.G. (2003), Network competence: Its impact on innovation success and its antecedents. Journal of Business Research, 56(9), 745-755.

Roberts, P. W., \& Amit, R. (2003). The dynamics of innovative activity and competitive advantage: The case of Australian retail banking, 1981 to 1995. Organization Science, 14(2), 107-122.

Rogers, E. M. (2003). Diffusion of innovations. New York, NY: Free Press.

Rosenbusch, N., Brinckmann, J., \& Bausch, A. (2011). Is innovation always beneficial? A meta-analysis of the relationship between innovation and performance in SMEs. Journal of Business Venturing, 26(4), 441-457.

Ruzzier, M., Antoncic, B., Hisrich, R. D., \& Konecnik, M. (2007). Human capital and SME internationalization: A structural equation modeling study. Canadian Journal of Administrative Sciences, 24(1), 15-29.

Saarenketo, S., Puumalainen, K., Kuivalainen, O., \& Kyläheiko, K. (2004). Dynamic knowledge-related learning processes in internationalizing high-tech SMEs. International Journal of Production Economics, 89(3), 363-378.

Samiee, S., Walters, P. G. P., \& DuBois, F. L. (1993). Exporting as an innovative behaviour: An empirical investigation. International Marketing Review, 10(3), 5-25.

Sullivan, D. (1994). Measuring the degree of internationalization of a firm. Journal of International Business Studies, 25(2), 325-342.

Tether, B. S. (2005). Do services innovate (differently)? Insights from the European innobarometer survey. Industry and Innovation, 12(2), 153-184.

Tidd, J. (2001). Innovation management in context: environment, organization and performance. International Journal of Management Reviews, 3(3), 169-183.

Tidd, J., \& Bessant, J. (2009). Managing innovation: Integrating technological, market and organizational change. Chichester: John Wiley \& Sons Ltd.

Toivonen, M., \& Tuominen, M. (2009). Emergence of innovations in services. The Service Industries Journal, 29(7), 887-902.

Trott, P. (2008). Innovation management and new product development (4th ed.). Pearson education: Harlow.

Westhead, P., Wright, M., \& Ucbasaran, D. (2001). The internationalization of new and small firms: A resource-based view. Journal of Business Venturing, 16(4), 333-358.

Zahra, S. A. (2003). International expansion of U.S. manufacturing family businesses: The effect of ownership and involvement. Journal of Business Venturing, 18(4), 495-513.

Zahra, S. A., \& Garvis, D. M. (2000). International corporate entrepreneurship and firm performance: The moderating effect of international environmental hostility. Journal of Business Venturing, 15(5/6), 469-493.

Zahra, S. A., Ireland, R. D., \& Hitt, M. A. (2000). International expansion by new venture Ffirms: International diversity, mode of market entry, technological learning, and performance. Academy of Management Journal, 43(5), 925-950.

Zahra, S. A., Ucbasaran, D., \& Newey, L. R. (2009). Social knowledge and SMEs' innovative gains from internationalization. European Business Review, 6(1), 81-93. 


\section{Appendix A. Selected survey items}

\section{Service innovation:}

To what extent (1-7) do the following statements describe the service(s) offered by your firm?

- Our service(s) offer unique benefits to the customer, not offered by competitors.

- Our service(s) rely on technology, which has never been used in the industry before.

- Our service(s) are not radically different from competitor services.

- Our service(s) provide higher quality than the competitors.

- Our service(s) are highly innovative, replacing a vastly inferior alternative.

- $\quad$ Our service(s) offers solutions that are not possible to achieve with existing products."

\section{Degree of internationalization:}

- Please estimate the percentage of your company's total sales which are attributable to foreign sales.

— less than $5 \%$ _ 6-10\% — $11-24 \%$ - $25-49 \%$ - $50-74 \%$ _ over $75 \%$

- Please estimate the percentage of your company's profits which are attributable to foreign profits.

— less than $5 \%$ — $6-10 \%$ — $11-24 \%$ _ $25-49 \%$ — $50-74 \%$ _ over $75 \%$

- Please estimate the percentage of your company's customers who are considered foreign customers.

— less than $5 \%$ _ 6-10\% — $11-24 \%$ - $25-49 \%$ - $50-74 \%$ _ over $75 \%$

- Please estimate the percentage of your employees that are located outside of the company's home country.

— less than $5 \%$ _ 6-10\% — $11-24 \%$ _ $25-49 \%$ _ $50-74 \%$ _over $75 \%$

\section{Growth:}

Please compare your firm over the past 3 years relative to the companies in the same industry (1-7) on the following criteria:

- Sales growth

- Growth in the number of employees

- Growth in market share

\section{International Performance:}

Please compare your firm over the past 3 years relative to the companies in the same industry (1-7) on the following criteria:

- Growth in international sales

- Growth in international profitability

- Creation of new foreign markets

\section{Industry:}

Please check the category that best describes your company's primary area of business:

- Manufacture of computer, electronic and optical products

- Wholesale of computers and other consumer electronics

- Software publishing

- Computer programming, consultancy and information service activities

- Software services

- Telecommunications

- Repair of computers and personal and household goods 